\title{
Hazard Analysis and Critical Control Point（HACCP）による食品の衛生管理
}

\author{
千葉隆司
}

\section{Management of Food Hygiene and Safety by Hazard Analysis and Critical Control Point (HACCAP)}

Takashi Chiba

Tokyo Metropolitan Institute of Public Health; 3-24-1 Hyakunin-cho, Shinjuku-ku, Tokyo 169-0073, Japan.

(Received August 3, 2021)

\begin{abstract}
Advances in food production technology and newer distribution systems have made it easier to obtain fresh ingredients from both within and outside of Japan. Although convenient, mass distribution of food over wide areas involves the risk of expanding the health damage caused by foods. Comprehensive management from production to consumption, using systems, such as hazard analysis and critical control point (HACCP), is required to ensure the safety of foods. Improved inspection methods are also required to detect the effects of environmental changes on food. In this paper, we demonstrate the use of "Methods of Analysis in Health Science 2020" for food hygiene and safety management.
\end{abstract}

Key words_ - food hygiene; hazard analysis and critical control point; contamination source

\section{はじめに}

近年, グローバル化の進展に伴いわが国のライフ スタイルは極めて多様になった。 それに合わせて消 費者が食に求める二ーズの幅は大きく広がり，現在 の市場には優れた食味を保持しつつ, 長期間保蔵で きる食品が流通している。 このような新しいタイプ の食品の製造は，高い生産技術と品質管理の厳格化 により成り立つており，原材料の受入れから製造, 流通，販売に至る物流に加え，消費までの各段階で 高いレベルの衛生管理が求められる.1)

現在，食品の製造における代表的な衛生管理手法 として hazard analysis and critical control point (HACCP）があり，わが国では昨年の法改正によ り，本手法の導入について義務化が図られた。

HACCP では, 各工程と最終製品について, 試験検 査等による安全性の評価を行う。

わが国での市販流通食品の微生物試験では，規格 基準や規範が示されている項目では法令等に記載さ れたいわゆる「公定法」が用いられ，規格基準がな

東京都健康安全研究センター（†169-0073 東京都新宿 区百人町 3-24-1)

e-mail: Takashi_Chiba@member.metro.tokyo.jp

本総説は, 日本薬学会第 141 年会シンポジウムS41 で

発表した内容を中心に記述したものである.
い項目では，多くの場合で「食品衛生検査指針」や 「衛生試験法・注解」，「ISO」等に示された方法が 参考にされる，公定法は，国内において公的に通用 する確かな試験法である一方で，多くは検査に時間 がかかる「培養法」が基本となっている，近年の食 品流通は広域化が進んでおり，可能な限り迅速な検 出法が求められる。 これに加えて，企業での自主検 査では簡便性やコストを低く抑えることも必要にな る.このような課題に対し, 近年, 分子生物学的な 手法を中心とした迅速な試験法が多く開発されてい る.

本稿では, 食品の衛生管理に資する微生物試験の 実応用例について, 日本薬学会の環境・衛生部会が 編さんする「衛生試験法・注解 2020」の内容を踏 まえつつ解説をする.

\section{1. 微生物による食品危害}

東京都内の食品事情を見ると，製造量よりも消費 量が圧倒的に多い，流通する食品の多くが海外を含 めた流入品であることは，食品に関連した事故発生 時の処理を複雑にする一因になっている. 都が行う 食の安全・安心に資する取り組みの中では，このよ うな地域特性を踏まえた仕組みづくりが求められ る. そこで, 食品に関連する各種の調査等を行い, 得られた結果はインターネット等を通じて随時提供 


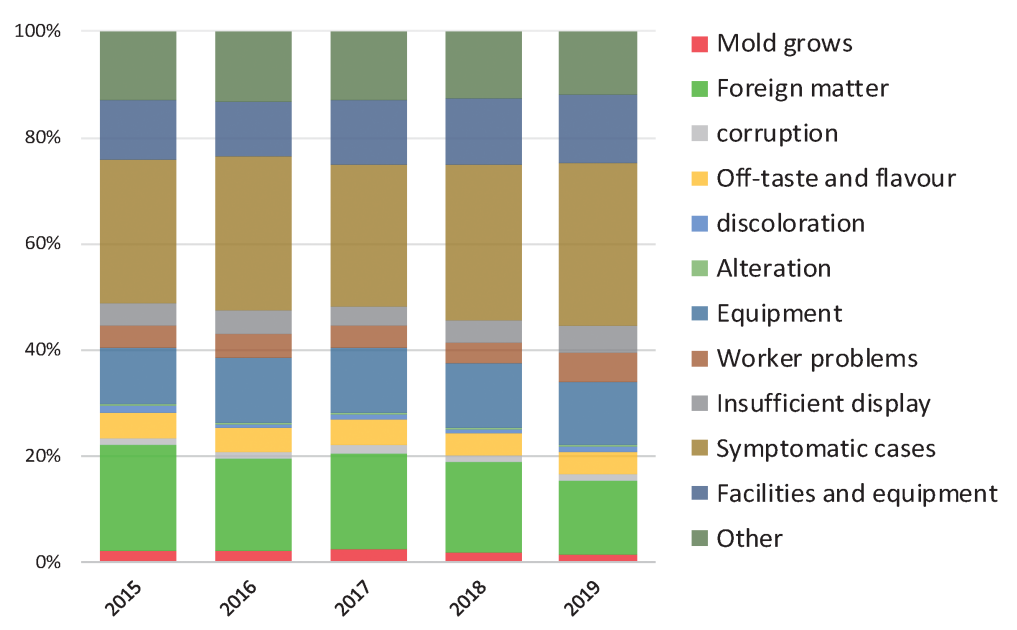

Fig. 1. Causes of Food Complaints in Tokyo (2015-2019)

し, 食の安全性確保の啓発を行つている.

具体例として, 都内の保健所などに寄せられた食 品の苦情を「苦情統計」として公開（http://www. fukushihoken.metro.tokyo.jp/shokuhin/kujou/ index.html）するとともに，発生頻度が高い事例は 「食品安全アーカイブス」にまとめている（https:// www.fukushihoken.metro.tokyo.lg.jp/shokuhin/ foods_archives/publications/index.html).

都内で発生した要因別食品苦情（過去 5 年間）を 見ると, 年間 5000 件程度の事案が発生している. この中で「カビの発生」として集計されている事案 は，全体の $2 \%$ に満たない（Fig. 1)。しかし実際に は, 異物や腐敗・変敗, 異味・異臭, 変色・変質な どで届け出られた苦情事例の中に, 試験によってカ ビ・酵母が原因とされる例が散見される（Fig. 2). このような事例を踏まえれば，食品に対するカビ・ 酵母の危害性は無視できる数ではない.

\section{2. 食品のカビ ·酵母試験法}

食品の微生物検査では, 対象となる食品に対して 危害性を有する菌を特定（同定）する作業が必要に

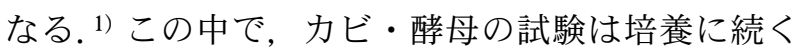
形態観察, 生理生化学性状を利用した「表現性状試 験」と, 遺伝子解析を中心とした「分子生物学的試 験（迅速同定法）」に大別される.これらの試験法 は, 衛生試験法・注解 2020 の中ではそれぞれ 「1.2.2 真菌」や「1.2.3.1 細菌および真菌の迅速 同定法」としてまとめられている.

食品のカビ・酵母試験では, 従来から表現性状試 験が広く用いられてきた。しかし, 長時間の培養や

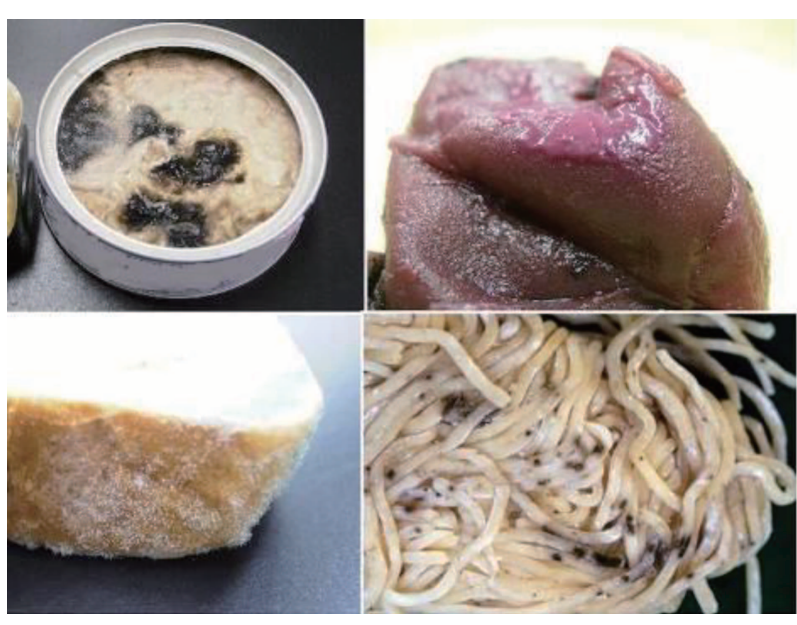

Fig. 2. Deterioration of Food Caused by Fungi (Molds and Yeasts)

煩雑な操作を伴う本法は, 日常的な衛生管理に用い る方法とは言い難く, 加えて, 実際には調理・加工 等により試験品中の微生物が死滅・損傷し，培養試 験が適用できないケースもある. ${ }^{2)}$ 近年，このよう な事例に対しては各種の分子生物学的な方法が利用 され, 以前では対応が難しかつた食品苦情事例の解 析が，積極的に行われるようになっている。このよ うな手法は食品中での微生物挙動の解明に加え, 製 造工場内等での污染実態調査や菌叢解析にまで応用 されており，得られた知見に基づいたさらに新しい 食品衛生管理の開発・導入も期待されている.

\section{3. 衛生管理での実例}

カビ・酵母に関連した衛生管理の実応用例として, 2 つの事例（チルドゆで湎の異物，レトルト食品の 異臭）で実施した対応を示す。 
3-1. 表現性状の確認（衛生試験法·注解 2020

「1.2.2 真菌」に準拠） チルドゆで湎の事例で は，苦情部位を肉眼及び実体・光学顕微鏡下で観察 （直接鏡検）した後，異物部分を無菌的に採取し， ポテトデキストロース寒天（PDA）培地（栄研化 学）に接種した。また，生産工場内で採取した最終 /中間製品，及びふき取り検体についても 10 倍乳剤 等をPDA 培地へ接種した。それぞれの培地につい $\tau 25^{\circ} \mathrm{C} ， 4-7$ 日間培養した後，発育した真菌につい て形態観察を行った.

また，レトルト食品の事例では食品全体を直接鏡 検した後， 10 倍乳剤を作製して PDA 培地で同様の 培養を行つた。

3-2. 分子生物学的試験（衛生試験法·注解 2020 「1.2.3.1 細菌および真菌の迅速同定法」を応用）

3-2-1. サンプルからの DNA 抽出 ゆで麺の 事例では，食品中に認められた異物と各検体からの 分離株をサンプルとした。 また，レトルト食品の事 例では検体の 10 倍乳剤の一部 $(2 \mathrm{~mL})$ をサンプル とし，それぞれアルカリ煮沸法2)で DNA を抽出し た.

3-2-2. 遺伝子解析 rRNA 遺伝子 (rDNA) 中の LSU-D1/D2 及び ITS 領域に設定したプライ マーを用いたダイレクトシーケンス法による塩基配 列解析と分子系統解析 ${ }^{2-5)}$ を実施した。

3-3. 異臭生成の確認（スチレン生成試験）

[衛生試験法·注解 2020 「1.2.2 真菌」及び 「4.1.1.3 理化学的試験, 49) 揮発性有機化合物, (1)-1 P\&T-GC/MSによる定量」を応用]

3-3-1. 供試菌株 当センター保存株 (Candida zeylanoides; 食品由来等 8 株, Saccharomyces cerevisiae; 食品由来 1 株), に加え, 独立行政法人 製品評価技術基盤機構から購入した Debaryomyces hansenii/Candida famata（NBRC0083）1株を供試 した.

3-3-2. スチレン生成試験＼cjkstart既報6) を参考に， GY 培地にケイ皮酸を加えた培地 $(0.01 \% \mathrm{GYC}$ 培 地）を用いた。 また，市販焼き芋 (滅菌及び未滅菌) の 10 倍乳剤を作製し，それぞれに被検菌を添加し た。それぞれ， $25^{\circ} \mathrm{C} て ゙ 4$ 日間培養した後，培養液 の遠心上清を MillQ 水で 100 倍に希釈し，パージ \&トラップ (P\&T) GC/MS システム（P\&T 部 : AQUAPT 5000J PLUS（ジーエルサイエンス）,

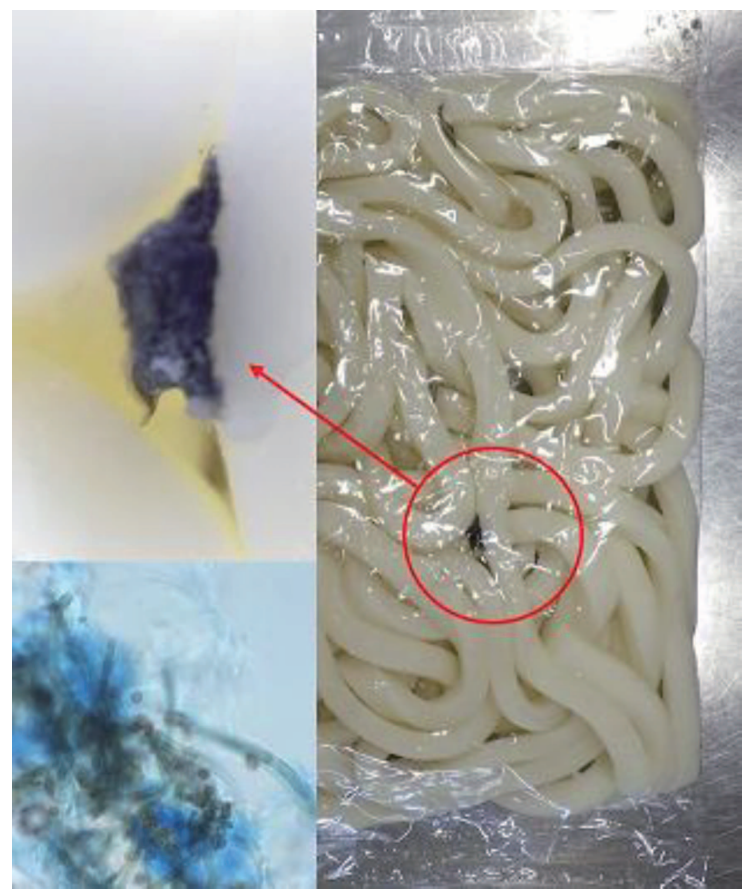

Fig. 3. A Case of Foreign Material in Boiled Noodles (Dematiaceous Fungi)

GC/MS 部：7890A（アジレント)/JMS-Q1050（日 本電子)）を用いて揮発性成分の分析を行った.

事例 1 チルドゆで麺の黒色異物

本事例は，クレームの原因菌（起因菌）が自然界 に広く分布する菌種と推定され, ${ }^{1)}$ 污染経路の特定 においてより詳細な株レベルの識別が必要になった 事例である.

チルドゆで麺中に黒色の異物が認められ，直接鏡 検では黒色菌糸様部分が多数認められた（Fig. 3). しかし，培養検査ではカビの発育が認められず，本 品は包装後に蒸気殺菌工程があったことから, 起因 菌は既に死滅していたものと推定された。 そこで, 異物の一部について塩基配列解析を行つた結果，同 異物は Cladosporium sphaerospermum の菌塊であ ることが判明した。

クレームがあった製品が未開封であったことか ら，異物は製造工程のどこかで混入したものと推定 された。そこで，異物（カビ）の混入経路を推定す るために工場内で採取した中間製品と製造ラインか らふき取り検体（計 15 検体）を採取した。培養検 查により，11 検体から真菌が検出され，このうち 5 検体からC. sphaerospermum が分離された.

一方，C. sphaerospermum は食品を含めた環境 
中から広く分離されるクロカビの一種であり，菌種 を同定しただけでは混入（污染）経路の推定には至 らなかった。そこで，分離した 5 株に異物由来株を 加えた計 6 株を用いた分子系統解析を行った。その 結果，工場内で検出した C. sphaerospermum は大 きく2つの系統に分かれることが判明し，異物由来 株は製造ライン最上流部の給水管付着物（菌塊）か ら分離した株（130018） と同系統（ブートストラッ プ值 96\%）であることが示された。

以上の結果から，本事例は食品製造ラインの清掃 が不十分であったため，ライン上流部(給水管周辺) で C. sphaerospermum が繁殖の後に剥がれ落ち, 混入したものと推定された。 そこで，改めて細部配 管を含む製造ライン（原材料から製品包装まで）を 定期的に清掃・確認する対応を取った。

事例 2 レトルト食品の異臭

本事例は，機器分析を含む試験検査を複合的に利 用し, クレームの原因として微生物の関与を否定し た事例である.

都内で発生する食品の苦情のうち, 食品中で力 ビ・酵母が発する異臭による届け出事例が少なくな い.7)このうち, Pichia anomala（現在はWickerhamomyces anomalus に菌名変更）に代表される 酶酸エチル産生酵母による苦情（シンナー臭）の頻 度が高い.1,2)一方，都内での発生頻度は多くない が，過去事例で特定の酵母が食品に含まれるケイ皮 酸を分解し，スチレンを産生することで異臭（ガソ リン/灯油/石油臭）を生じたケースが報告されてい る. ${ }^{6)}$ 本事例はレトルト製の焼き芋で開封時に強い 石油様の異臭を認め，届け出時点では酵母の関与が 疑われていた。 クレーム品は外観に異常を認めず, 培養検査でもカビ・酵母の発育が認められなかつ た。製造に加熱工程があったため，原因菌が死滅し ている可能性が疑われたため, 食品から DNA を直 接抽出し，塩基配列解析を行った。 その結果，酵母 の一種 C. zeylanoides の DNA が検出された.

同菌種については，スチレン産生が報告されてい なかったことから, ${ }^{8}$ 当所の保存株（8 株）を対象 にスチレン産生試験を実施した結果，すべての株で スチレンの産生は認められなかった（Figs. 4 and 5)。また，スチレン以外の異臭産生を確認するため, C. zeylanoides の市販焼き芋（滅菌/未滅菌）への 接種試験を行った。その結果，臭気の異常はみられ

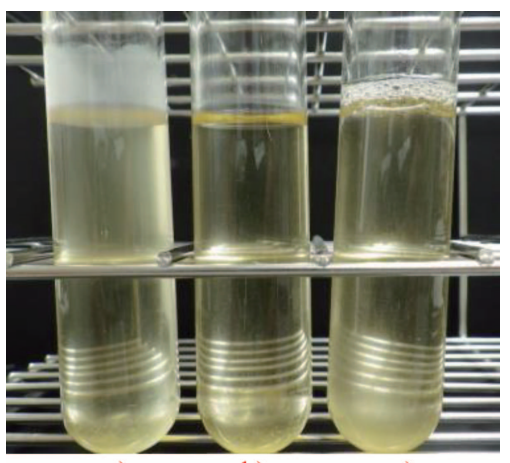

a)

b)

c)

Fig. 4. Yeasts Growth in $0.01 \% \mathrm{GYC}$ Medium a) D. hansenii, b) C. zeylanoides, c) S. cerevisiae.

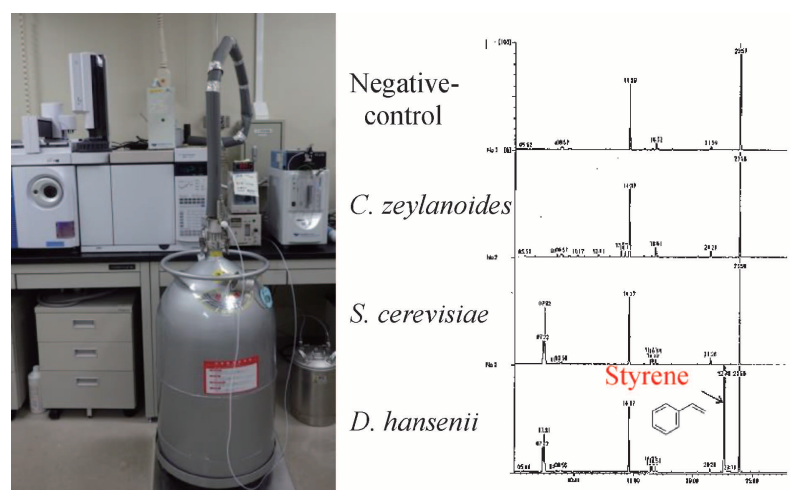

Fig. 5. Detection of Food Off-flavor (Styrene) Using Purge and Trap-GC/MS Method

ず，機器分析においても微量のアルコール産生以外 は認めなかった。

以上の結果から, クレーム品で検出された $C$. zeylanoides による臭気産生の可能性は否定され た。また，同時に行った理化学分析により異臭成分 が灯油に類似していることが判明し，この結果を基 に製造業者へ確認したところ，製品の加工に使用し ていた灯油が混入していた可能性が疑われ，工程を 見直す対応を取った。

\section{4. まとめ}

本稿では, 食品の安全性を微生物学的な側面から 確保するための各種の試験検査について，実応用例 を基に紹介した，食品の事故・苦情を低減していく 過程では，個々の事例について試験検査を通じて原 因を究明した上で，得られた知見を蓄積・共有し， 衛生管理全体の底上げをすることが求められるが, 実際の微生物試験では，起因菌の死滅や損傷，難培 養な菌種等により培養法を中心とした表現性状試験 が適用できない例が少なからず存在する. ${ }^{2,9)}$ そのよ 
うな場合は分子生物学的な試験法が選択されるが, 本法は迅速性や客観性にも優れていることもあり, ともすれば，すべて分子生物学的な試験法で賄える との見方もある. しかし, 事例 2 でも示した通り, 実態解明の最終段階では危害が発生した状態を確認 するための「接種試験/再現実験」が必要になる例 も存在する.さらに, 衛生管理に資する多角的な事 例解析の中では, 過去の事例との菌株比較も求めら れ，各事例において可能な限り菌株を分離し，又 トックしておくことも重要な作業になる.

上記に加え, 実際の衛生管理においては, 試験法 の選択において幅広い視野を持つ必要がある。近 年, 試験検査の方法が大きく進展した結果, それぞ れが専門特化している，結果として，試験を実施す る際の参考成書は「微生物試験」と「理化学試験」 のような形で分冊化され，内容についても細分化さ れている場合が多い。そのような中, 「衛生試験法・ 注解」は微生物試験法について表現性状試験から分 子生物学的な試験法までを解説している上, 機器分 析法, 遺伝毒性試験法, 放射能試験法などの一般試 験法から飲食物, 環境の試験法までを 1 冊で幅広く 網羅した成書である. 今回, 衛生試験法・注解から 食品事故の実態解明に資する試験法のヒントを得る ことができた.このことから, 改めて食品の衛生管 理に携わる当学会の会員を中心に, 同書の積極的な 活用を期待したい. 利益相反＼cjkstart開示すべき利益相反はない.

\section{REFERENCES}

1) Morozumi S., Fujikawa H., Wauke T., Chiba T., Ann. Rep. Tokyo Metr. Inst. P.H., 55, 312 (2004).

2) Chiba T., Wauke T., Sadamasu K., Yano K., Morozumi S., J. Food Hyg. Soc. Jpn., 48, 1-7 (2007).

3) Kurtzman C. P., Robnett C. J., J. Clin. Microb., 35, 1216-1223 (1997).

4) White T. J., Bruns T., Lee S., Taylor J., "PCR Protocols: A Guide to Methods and Applications," ed. by Innis M. A., Gelfand D. H., Sninsky J. J., White T. J., Academic Press, San Diego, 1990, pp. 315-322.

5) Tamura K., Dudley J., Nei M., Kumar S., Mol. Biol. Evol., 24, 1596-1599 (2007).

6) Morozumi S., Wauke T., Tamura Y., Kudoh Y., Jpn. J. Food Microbiol., 9, 113-119 (1992).

7) Fujikawa H., Wauke T., Morozumi S., Jpn. J. Food Microbiol., 22, 24-28 (2005).

8) Kurtzman C. P., Fell J. W., Boekhout T., “The Yeasts: A Taxonomic Study," 5th ed., Elsevier, Amsterdam, 2011.

9) Takahashi Y., Chiba T., Inomata A., Wauke T., Kai A., Yano K., Ann. Rep. Tokyo Metr. Inst. P.H., 59, 161-165 (2008). 